\title{
Transcription Factor HES-5
}

National Cancer Institute

\section{Source}

National Cancer Institute. Transcription Factor HES-5. NCI Thesaurus. Code C84297.

Transcription factor HES-5 (166 aa, $18 \mathrm{kDa}$ ) is encoded by the human HES5 gene. This protein may play a role in transcriptional repression. 